\title{
Stability Analysis of Dump Slope in Open Cast Mines \\ ${ }^{* 1}$ B. Shruthi, ${ }^{2}$ Vaishali J. Rajurkar, ${ }^{3}$ Sumit S. Geete \\ ${ }^{*} \mathrm{C}$ MPDI, RI4, Jarpatka, Nagpur, India \\ ${ }^{2,3}$ Civil Dept., Shri Ramdeobaba College of Engineering and Management, Nagpur, India \\ Email: 1'megastructure1857@gmail.com, ${ }^{2}$ rajurkarvj@rknec.edu, ${ }^{3}$ sumit.geete@gmail.com
}

slorer

Received: 22nd October 2019, Accepted: 20th November 2019, Published: 31st December 2019

\begin{abstract}
This paper present a case study of dump slope stability of Makardhokra - II open cast mine of western coalfield limited. This mine spread over the area of 289.0 hectares. Dump slope instability is the prime concern of proposed mine site. Depth of Black Cotton Soil is extended up to a depth of $20 \mathrm{~m}$ from the natural ground level. To assess the stability of the OBD slope, samples of dump material were collected from benches of OBD slope. Geotechnical parameters of dump material were evaluated mainly for black cotton soil and white soil. From the geotechnical and geometrical parameters, numerical models were created in software GEO5 for stability analysis and calculation of FoS. GEO5 worked on the Limit Equilibrium Method. The optimal and economical solution for dump slope management and for safety analysis, Geo5 software is used by considering three methods namely Bishop Method, Fellenius method and Spencer method. To check the suitability of improvement the stability of the OBD slope, cantilever wall of $2.75 \mathrm{~m}$ and $3.0 \mathrm{~m}$ with variation of backfilling from the inner face of the wall at distance of $0,0.5 \mathrm{~m}, 1 \mathrm{~m}$ and $1.5 \mathrm{~m}$ were evaluated through LEM. Feasibility of gabion wall for improvement of the stability of OBD was also checked. FoS was calculated by varying the slope angle of dump and replacement of black cotton soil with white soil. It is seen that as the angle of the slope increases then FoS decreases. Provision of gabbion wall and replacing black cotton soil of dump with white soil indicate the improved value of Fos. Because of restriction of land, feasibility of construction of retaining wall provision is discarded. Provision of cantilever wall and gabion wall increase the FoS of OBD slope. From cost analysis, cost of provision of cantilever wall is about $70 \%$ more than const of provision of gabion wall. Gabion wall proposed to be economical, suitable, easily workable and sustainable method for stability of OBD slope of Makardhokra - II open cast mine.
\end{abstract}

Keywords

Over Burden Dump (OBD), Dump Slope Stability, Factor of Safety (FoS), Cantilever Retaining Wall, Gabion Wall

\section{Introduction}

Open Cast mining of coal activity increases day by day to fulfill the demand of the coal for power generation sector. As the depth of the coal mines goes downwards from the existing ground level then the extracted material quantity increases. This extracted quantity of the material called as overburden dump material (OBD) and it is stored in the form of dump. OBD are of two types namely Internal Pit Dump (IPD) and External Over Burden Dump. Dumping of large quantity of extracted material is major problem in the mining industry and again it relates to the optimum use of land for the dump material storage [11]. Stability of the OBD slope is depends on shear strength of the material. Shear strength of soil correlated to the cohesion and angle of internal friction. Stability of the OBD slope is mainly governed by the geotechnical parameters of the OBD material $[3,10]$. Stability of the dump slope is govern by geological, geometrical, hydraulic and physico-mechanical factors of dump slope material [9]. Pore pressure is main critical factor to reduce the Stability of the OBD slope through reduction in the shear strength of the OBD material [10]. Stability of OBD slope is improved through plantation of the vegetation on the external surface of the OBD slope. Penetrated roots of the plantation increases the cohesion of small thickness of dump slope [6]. Stability analysis methods mainly find out probable failure envelope and factor of safety (FoS). Limit equilibrium methods (LEM) are mainly used to calculate the FoS of the OBD slope and LEM mainly consider failure envelope as circular $[4,8]$. Strength reduction method based on the numerical modeling also very useful to calculate the probable failure surface and calculation of the FoS [1].

\section{Methodology}

Slope stability of the OBD slope is analyzed through LEM methods. For stability analysis, geometrical parameters of OBD material are evaluated in the laboratory. Major deposit found in area i.e. black cotton soil, in some of the areas of site white soils are observed which has non swelling in nature. The various index and engineering properties of both soils are determined in laboratory as shown in Table 1. 


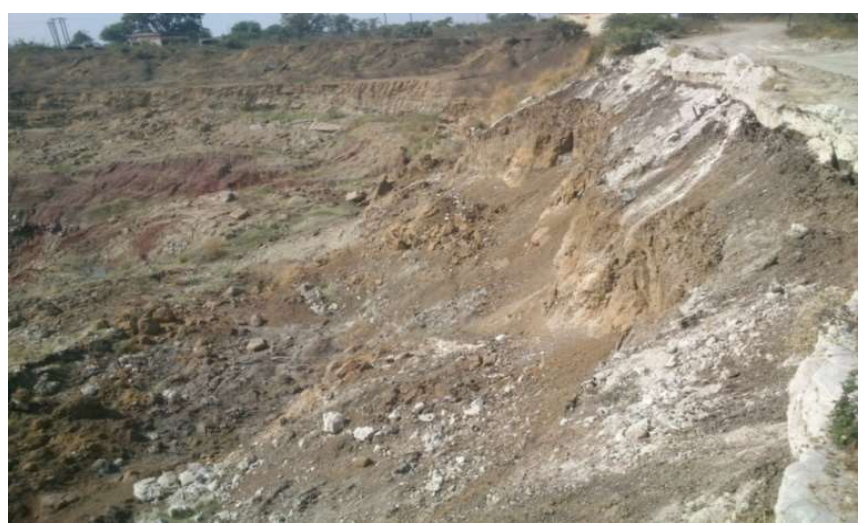

Figure 1: Photograph of Overburden Dump Makardhokra - II OC Mine, Umrer Nagpur

\begin{tabular}{|c|c|c|c|c|}
\hline $\begin{array}{l}\text { Evaluation of } \\
\text { Properties of } \\
\text { OBD Material }\end{array}$ & $\begin{array}{l}\text { Developement } \\
\text { of Model on } \\
\text { Geo5 Software }\end{array}$ & $\begin{array}{l}\text { Analysis of } \\
\text { OBD Slope by } \\
\text { LEM Method } \\
\text { and } \\
\text { Calculation of } \\
\text { FoS }\end{array}$ & $\begin{array}{c}\text { Analysis of } \\
\text { Slope with } \\
\text { Provision of } \\
\text { Counterfort } \\
\text { Retaining Wall } \\
\text { and } \\
\text { Calculation of } \\
\text { FoS }\end{array}$ & $\begin{array}{l}\text { Analysis of } \\
\text { Slope with } \\
\text { Provision of } \\
\text { Gabbian Wall } \\
\text { and } \\
\text { Calculation of } \\
\text { FoS }\end{array}$ \\
\hline
\end{tabular}

\section{Study Area Description}

Figure 2: Methodology for Stability Analysis of OBD Slope

The proposed study is of Makardhokada-II open cast coal mines of Western Coal Filed Limited (WCL) of Nagpur area, Maharashtra, India which is located within longitude $20^{\circ} 51^{\prime} 00^{\prime \prime}$ to $20^{\circ} 53^{\prime} 30^{\prime \prime}$ and latitude $79^{\circ}$ $11^{\prime} 10^{\prime \prime}$ to $79^{0} 15^{\prime} 55^{\prime} \mathrm{E}$. It has huge coal reserve spread over the area of 289 hectares shown in figure 1. Existing OBD consist of three number of benches. However, this region is very prone to dump instability as the area is covered by black cotton soil up to the depth of nearly 20 meters, which is expansive in nature. Width and height of the existing dump are $15 \mathrm{~m}$ and $10 \mathrm{~m}$ respectively. The primary purpose of the slope stability analysis is to determine to the safe and economic design of mine overburden dump.

\section{Geotechnical Properties of OBD Material}

Samples of OBD materials collected from benches of the mine site were analyzed for geotechnical investigation like sieve analysis, moisture content, Optimum Moisture Content (OMC), Maximum Dry Density (MDD), Specific Gravity and Bulk density according to Indian standard codal provisions. Direct shear test carried out for OBD material at OMC to evaluate the vales of cohesion (c) and angle of internal friction (ø) for calculating the shear strength of the OBD.

\begin{tabular}{|l|l|l|}
\hline 1 & Specific Gravity & $\begin{array}{l}\text { Black cotton Soil }: 2.48 \\
\text { White Soil }: 2.64\end{array}$ \\
\hline 2. & Bulk in-situ density & $\begin{array}{l}\text { Black cotton Soil }: 17.3 \mathrm{kN} / \mathrm{m}^{3} \\
\text { White Soil }: 19.35 \mathrm{kN} / \mathrm{m}^{3}\end{array}$ \\
\hline 3. & Grain size analysis & $\begin{array}{l}\text { Black cotton Soil }: \text { Highly compressible } \\
\text { White Soil : clayey sand clay with low plasticity }\end{array}$ \\
\hline 4. & Liquid limit & $\begin{array}{l}\text { Black cotton Soil }: 51 \% \\
\text { White Soil }: 33 \%\end{array}$ \\
\hline 5. & OMC and MDD & $\begin{array}{l}\text { Black cotton Soil }: \text { OMC } 22.34 \% \text { and } \mathrm{MDD}=16.33 \mathrm{kN} / \mathrm{m}^{3} \\
\text { White Soil }: \text { OMC } 14.40 \% \text { and } \mathrm{MDD}=19.0 \mathrm{kN} / \mathrm{m}^{3}\end{array}$ \\
\hline 6. & Direct Shear Test & $\begin{array}{l}\text { Black cotton Soil }: \mathrm{C}=67.75 \mathrm{kN} / \mathrm{m}^{2}, \varnothing=2.5^{0} \\
\text { White Soil }: \mathrm{C}=9.475 \mathrm{kN} / \mathrm{m}^{2}, \varnothing=19^{0}\end{array}$ \\
\hline
\end{tabular}

\section{Table 1: Soil Properties}

\section{Stability Analysis}

Stability of dump slope without retaining wall was analyzed using limit equilibrium method with the help of the Geo5 software. Numerical models created to evaluate the slope stability of dump without and with retaining wall. Variation of Factor of safety with respect to various slope angle is calculated in case of a) Natural slope without any retaining wall and partial replacement of white soil to black cotton soil b) Cantilever Retaining 
wall and c) Gabion wall as retaining wall. Factor of safety has been calculated by software using three methods namely Bishop Method, Fellenius method and Spencer method. The results and its analysis are shown below.

Results and Discussion
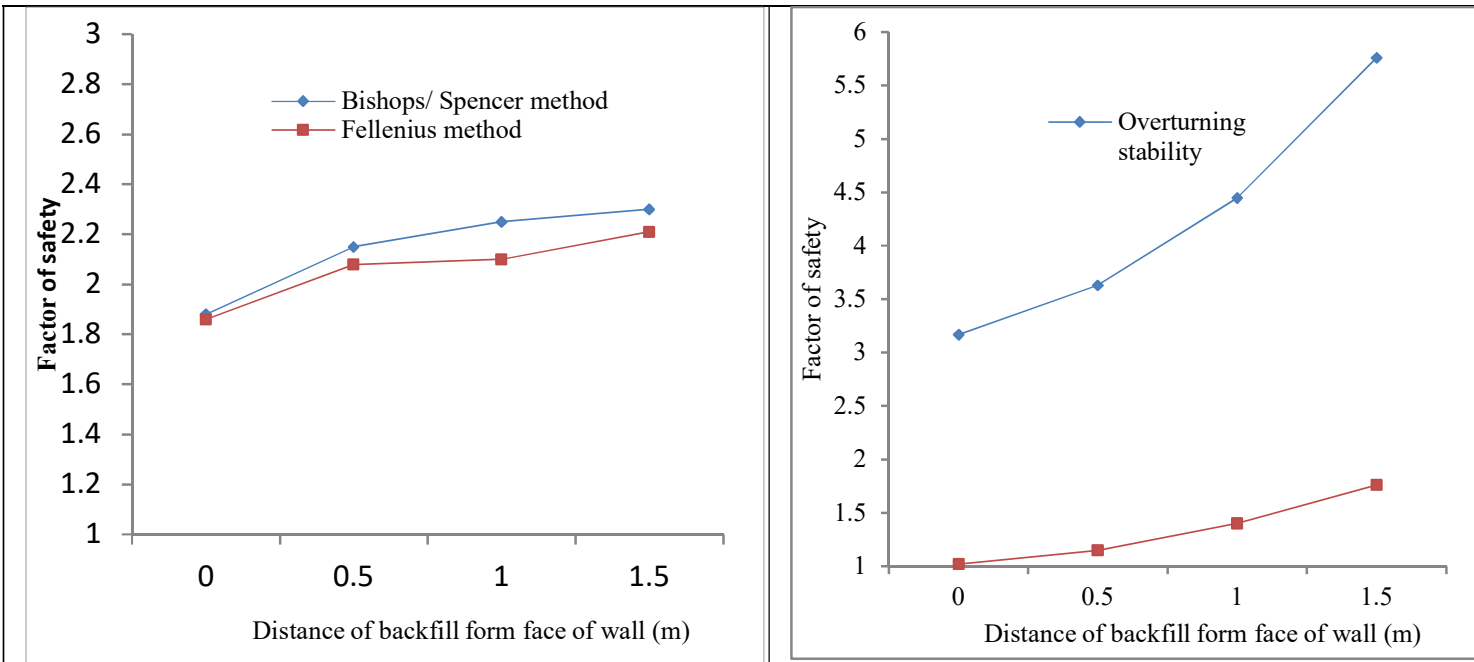

\section{Graph 1: Variation of Distance of Backfill from Face Cantilever Wall for 3 m Height with FoS}

Graph 2: Variation of Distance of Backfill from Face Cantilever Wall for 3m Height with FoS for Center of Slip and Overturning Stability

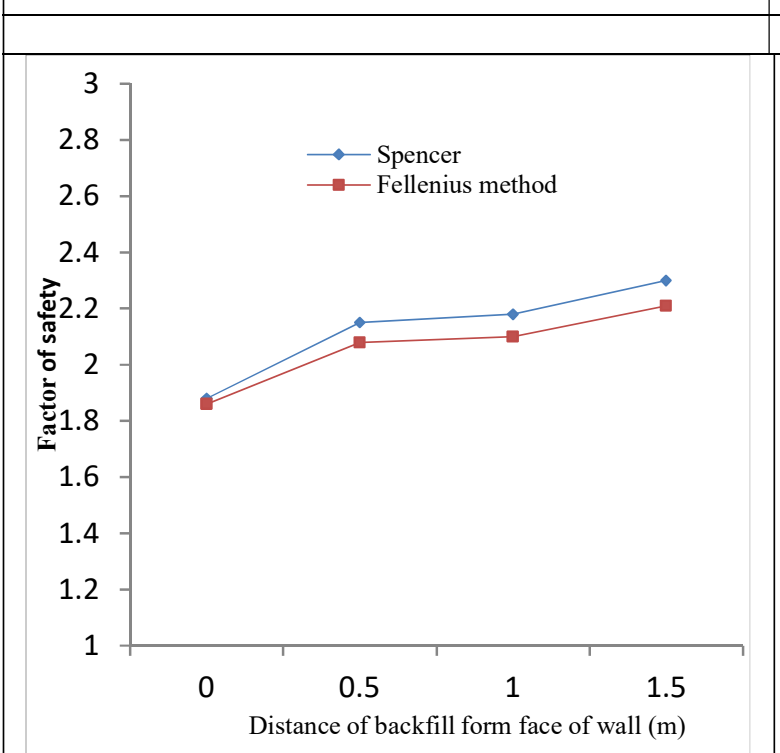

Graph 3: Variation of Distance of Backfill from Face Cantilever Wall for 2.75 m Height with FoS
Graph 4: Variation of Distance of Backfill from Face Cantilever Wall for 2.75 m Height with FoS for Center of Slip and Overturning Stability 


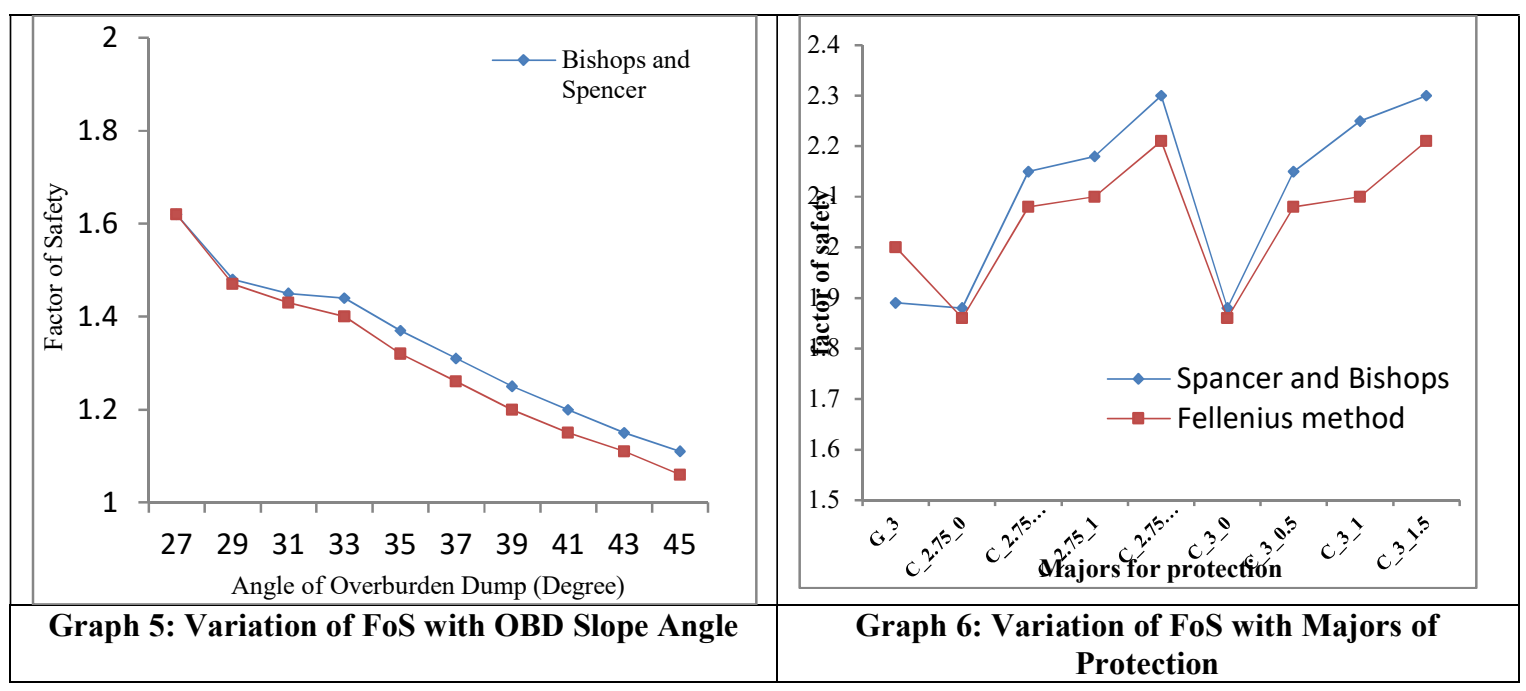

A $17.5 \mathrm{~m}$ dump slope consisting of low highly swelling and low strength material subjected to failure mainly in rainy season. Which was analyzed for slope angle optimization and the results are obtained for different corrective majors. After studying the various models in software, Graph 5 shows the variation of the dump slope angle and its factor of safety; the stability analysis has been made by 3 methods as mention above. Bishops and Spencer methods shows similar nature for all cases of slope stability; shows slightly greater values than Fellenius method.

Slope angle plays an important role in dump slope management. Increase in angle of slope reduces its stability and hence its factor of safety. After analysis it is observed that slope is stable i.e. factor of safety is more than 1.5 at an angle of 27 degree without any retaining wall and just by partial replacement of black cotton soil. Whereas for this safe slope the length required for laying dump is more than $40 \mathrm{~m}$ and length restricted to $40 \mathrm{~m}$. Therefore other method using cantilever retaining wall and gabion wall have been studied.

Analysis using cantilever retaining wall is done for different heights of retaining wall i.e. for $3.0 \mathrm{~m}$ and $2.75 \mathrm{~m}$ height. The stability analysis has been also done for different position of dump slope from the face of the retaining wall. Graph 1 shows the variation of distance of backfill from face cantilever wall for $3 \mathrm{~m}$ height with FoS; the slope is safe for all distances of backfill however it is observed that increasing in distance of backfill from the face of wall more is the factor of safety. Graph 2 shows that the retaining wall is more safe overturning stability for all the distances; but it is not safe for centre of slip plane up to the distance of $1.5 \mathrm{~m}$. This is mainly because as the distance of the slope from retaining wall increases, the earth pressure decreases on the retaining wall.

Similar relations was plotted for $2.75 \mathrm{~m}$ height cantilever retaining wall; graph 3 and 4 shows the similar trend and observed that the slope is safe for all distances of backfill perhaps for centre of slip plane is safe after the distance of $1.5 \mathrm{~m}$. Therefore while designing the slope this stability has to check carefully.

Analysis has been also done for different thickness of base slabs and different dimensions of toe and heel length of cantilever retaining wall. As the thickness of base slab and dimension of toe and heel length shows linear relation, decreased in dimensions of, factor of safety also decreases but it is within the permissible limits. This enables us to make the cantilever retaining wall even more economical.

Analysis using gabion wall is also done for different heights of wall i.e for $4.0 \mathrm{~m}$ and $3.0 \mathrm{~m}$ height. Analysis has been also done for different position of dump slope from the top of gabion wall. It was found that the gabion wall is safer in slip as the distance of slope increases from the top of the gabion wall. It was also found that in case of $4 \mathrm{~m}$ height gabion wall, the wall is safe in slip if the slope starts $3 \mathrm{~m}$ away from the top of the gabion wall. But in case of gabion wall of $3 \mathrm{~m}$ height, the wall is safe even if the slope starts immediately from the top of the gabion wall. This is mainly because the earth pressure decreases drastically in case of gabion wall of $3 \mathrm{~m}$ height than the gabion wall of $4 \mathrm{~m}$ height.

Graph 6 shows the variation of FoS with majors of protection calculated by Bishops and Spencer methods shows similar nature for all cases of slope stability. From the stability analysis with the majors, highest factor of safety is obtained in all the cases of wall, for backfill is placed at $1.5 \mathrm{~m}$ distance away from the face of wall. As the distance of backfill increases from the face of wall, radius of slip circle is also increases which increases the frictional efforts required to resist dump slope failure. 


\section{Conclusion}

The following conclusions can be drawn from the work done:

1. As the flattering of slope is safe and considered to the economical solution due to filling of dump from the site is used in above case, but not suggested to use due to restricted space is available over the site.

2. As the construction of $2.75 \mathrm{~m}$ cantilever retaining wall shows fare results but the construction cost of such wall comes out to be 43.05 lakhs ( Calculated as per CSR 2016-17)

3. The other alternative for the stability of slope is gabion wall; the cost of Gabion wall comes out to be 24.96 lakhs. (Calculated as per CSR 2016-17). This makes the gabion wall method more economical. The cost of Cantilever wall is nearly around $70 \%$ higher than the cost Gabion wall.

4. Gabion wall also has some other advantages like it can be removed and reused if needed. As the mine life is very less, it is generally advisable to use temporary construction Moreover as the mine is not permanent; gabion wall is more advisable for temporary construction. Gabion wall doesn't allow developing hydrostatic pressure and pore water pressure is easily dissipated in this case.

5. Construction of Gabion wall is very fast, On other side cantilever wall is very expensive, requires more construction time, skilful workmanship and it is a permanent kind of structure. Whereas Gabion construction is very eco friendly as it allows the growth of vegetation.

6. As the existing soil available is the Umrer region is black cotton soil which is subjected to swelling in rainy season which leads to increase in earth pressure due to increase in unit weight. Also the soil is subjected to pore water pressure. The use of Gabion wall provided drainage to disperse the pressure of water flowing through backfill soil which also allows good natural drainage. Therefore, it is suggested to use Gabions for the stability of dump

\section{References}

1. Chaulya, S. K., R. S. Singh, M. K. Chakraborty, and B. B. Dhar. 1999. "Numerical Modelling of Biostabilisation for a Coal Mine Overburden Dump Slope.” Ecological Modelling 114(2-3): 275-86.

2. Dawson, E. M., W. H. Roth, and A. Drescher. 1999. "Slope Stability Analysis by Strength Reduction." Géotechnique 49(6): 835-40. http://www.icevirtuallibrary.com/doi/10.1680/geot.1999.49.6.835.

3. Igwe, Ogbonnaya, and Chidinma Chukwu. 2018. "Slope Stability Analysis of Mine Waste Dumps at a Mine Site in Southeastern Nigeria." (2004).

4. Jeppson, Roland W, Robert W Hill, and C Earl Israelsen. 1974. "Slope Stability of Overburden Spoil Dumps from Surface Phosphate Mines in Southeastern Idaho.” (January).

5. Ranjan, Vibhash, Phalguni Sen, Dheeraj Kumar, and Arjun Saraswat. 2017. "Enhancement of Mechanical Stability of Waste Dump Slope through Establishing Vegetation in a Surface Iron Ore Mine." Environmental Earth Sciences 76(1): 377-88.

6. Ranjan, Vibhash, Phalguni Sen, Dheeraj Kumar, and Arjun Sarsawat. 2015. "A Review on Dump Slope Stabilization by Revegetation with Reference to Indigenous Plant." Ecological Processes.

7. Rochelle, P L A et al. 2012. "Enhancement of Mechanical Stability of Waste Dump Slope through Establishing Vegetation in a Surface Iron Ore Mine." Environmental Earth Sciences 76(1): 377-88. http://dx.doi.org/10.1007/s12665-018-7743-5.

8. The, Introduction, Simplified Bishop, and The Newton-raphson. 1977. "Comparison of Slope Stability Methods of Analysis1."

9. Upadhyay, O. P., D. K. Sharma, and D. P. Singh. 1990. "Factors Affecting •stability of Waste Dumps in Mines." International Journal of Surface Mining, Reclamation and Environment 4(3): 95-99.

10. Verma, Abhiram Kumar, and Debasis Deb. 2017. "Stability Analysis of a Mine Waste Dump over an Existing Dump.” Journal of Mines, Metals and Fuels (February).

11. Zevgolis, Ioannis E. 2018. "Geotechnical Characterization of Mining Rock Waste Dumps in Central Evia, Greece.” Environmental Earth Sciences 77(16): 0. http://dx.doi.org/10.1007/s12665-018-7743-5. 